\title{
Productivity and quality of grapevine yield when using micronutrient fertilizers of new generation in the conditions of Crimea
}

\author{
Natalia Aleynikova*, Evgenia Galkina, Pavel Didenko, Vladimir Andreev, and Carina \\ Zaripova
}

All-Russian National Research Institute of Viticulture and Winemaking Magarach of the RAS, 298600 Yalta, Russia

\begin{abstract}
The article presents the results of studies of 2019-2020, carried out in the soil and climatic conditions of Crimean Mountain-valley viticultural zone on table grape variety 'Italia'. It was experimentally determined that five-fold foliar treatment of grape plantations with gel fertilizers has led to a significant increase in the average length of annual shoots by $15 \mathrm{~cm}(9.2 \%)$ and an increase in the green matter of bushes by $165.1 \mathrm{~cm}^{3}(9.1 \%)$. It was found that using of preparations of experimental system of mineral nutrition manufactured by Agrinos and Lima-Europe companies during two growing seasons of grape plants has led to an increase in the average bunch weight by $42.9 \mathrm{~g}(7.4 \%)$, shoot productivity by $8.1 \%$ and an increase in the cropping capacity by $1.8 \mathrm{t} / \mathrm{ha}(10.2 \%)$ in comparison with the control. Using of the studied mineral gel fertilizers against the background of increasing grape productivity did not affect the process of sugar accumulation and the level of titratable acids. The studies showed that two-year fertilizer utilization of the studied system of mineral nutrition contributed to a significant increase in organoleptic characteristics of table grapes.
\end{abstract}

\section{Introduction}

Viticulture today is one of priority-oriented and most dynamically developing branches of agriculture in the Russian Federation. Currently the requirements for the quality of grape products are increasing and tightening: both for processing raw materials and table grapes, consumed fresh, including their ecological cleanliness. To solve the assigned tasks and increase the competitiveness of grape production, a complex of measures is annually applied on grape plantations, primarily aimed at obtaining proper yield and improving its quality [1-3].

One of such measures is adaptation of grape mineral nutrition systems. As established by scientific studies, grape plants are deficient in macro- and microelements during active growing season. Mineral fertilizers have an impact on growth of shoots, setting of fruit rudiments in buds of wintering eyes, leaf coverage of bushes. Foliar treatments with mineral fertilizers promote activation of a number of metabolic processes in plants,

\footnotetext{
* Corresponding author: pavel-liana@mail.ru
} 
especially under unfavorable (stressful) growing conditions, improve grape yield, reduce ripening period, increase nutritional value of berries, and raise disease resistance [4-7].

High efficiency of foliar dressing in conditions of insufficient moisture, as very important for the development of sustainable viticulture in Crimea, is also its essential characteristic.

Thus, the purpose of our work was to evaluate the effect of mineral nutrition system with gel fertilizers of new generation on the productivity of grape plantations, qualitative and organoleptic characteristics of light-colored table grape variety 'Italia'.

\section{Study objects and methods}

Field studies were conducted in 2019-2020 on industrial plantations of table grape variety 'Italia' of Crimean Mountain-valley viticultural zone (Privetnoye branch, FSUE PJSC Massandra).

The type of research is a field production experiment. Planting year of vineyard is 2003, planting scheme - $3 \times 1.5 \mathrm{~m}$; bush training - one-armed cordon on a medium trunk; rootstock - 'Berlandieri x Riparia Kober 5BB'; without irrigation. The soil of the plot is alluvial deluvial, sub-saline, medium-rank-stony, heavy clay-loamy, depth of humus horizon is 100 $\mathrm{cm}$. The area of the variant is 2 hectares. Experimental variants are located by the method of lengthened plots and each variant consists of 45 bushes chosen for accounting in triplicate [8]. Method of application is a tractor spraying (OPV-2000). The rate of working fluid consumption is $1000 \mathrm{l} / \mathrm{ha}$.

The research scheme included two systems of mineral nutrition of grapes: experimental (five-fold foliar top dressing with the studied fertilizers) and the control (system of nutrition adopted in the farming enterprise, Table 1).

Table 1. Scheme of research.

\begin{tabular}{|c|c|c|c|}
\hline Variant & Title of fertilizer & $\begin{array}{l}\text { Applicatio } \\
\text { n rate }\end{array}$ & $\begin{array}{l}\text { Stages of processing } \\
(\mathrm{BBCH})\end{array}$ \\
\hline \multirow{3}{*}{$\begin{array}{l}\text { Control: } \\
\text { farming } \\
\text { system of } \\
\text { nutrition }\end{array}$} & $\begin{array}{l}\text { 1) Double Win }(20: 20: 20)+ \\
\text { Humiful }\end{array}$ & $2+0,1$ & $\begin{array}{c}\text { «inflorescences clearly } \\
\text { visible» }\end{array}$ \\
\hline & 2) Double Win K + Humiful & $2+0,1$ & «berries pea-sized» \\
\hline & 3) Double Win P + Humiful & $2+0,1$ & «beginning of ripening» \\
\hline \multirow{5}{*}{$\begin{array}{l}\text { Experiment: } \\
\text { system of } \\
\text { nutrition } \\
\text { under study }\end{array}$} & $\begin{array}{l}\text { 1) Agrinos } 2+\text { Gel Calcibor }+ \text { Gel } \\
\text { Micro }\end{array}$ & $2+2+2$ & «beginning of flowering» \\
\hline & 2) Agrinos $2+$ Gel Fruit & $2+2$ & «end of flowering» \\
\hline & 3) Agrinos $2+$ Gel Fruit & $2+2$ & «berries pea-sized» \\
\hline & $\begin{array}{l}\text { 4) Agrinos } 2+\text { Gel Calcibor }+ \text { Gel } \\
\text { Fruit }\end{array}$ & $2+2+1$ & $\begin{array}{c}\text { «berries beginning to } \\
\text { touch» }\end{array}$ \\
\hline & 5) Agrinos $2+$ Gel Calciphos & $2+2$ & «beginning of ripening» \\
\hline
\end{tabular}

The composition of new generation gel fertilizers, presented in experimental system of nutrition, is as follows:

Agrinos 2 - contains a complex of bioavailable nutrients (protein, amino acids, nitrogen, potassium, carbon, magnesium, copper, iron, chitin and chitosan), which can activate metabolic processes and reduce negative impact of various stresses.

Gel Calcibor is a highly concentrated calcium fertilizer synergized with boron, $\mathrm{pH}$ buffer and special additives (wetting and adhesive substances), administration of the preparation is prophylaxis and treatment of plant diseases associated with calcium deficiency. 
Gel Micro is a multifunctional microelement complex for correcting nutrient deficiencies. Amino acids are included in composition for better absorption of microelements.

Gel Fruit - (N-P-K $+2 \mathrm{MgO}+$ microelements), is a mineral fertilizer, the action of which is aimed at improving ripening and color, increasing sugar content and fruit hardness.

Gel Calciphos is a complex mineral fertilizer that combines phosphorus with a high content of soluble calcium, magnesium, boron and zinc using gel technology.

Key advantage of using gel fertilizers is their balanced complex composition of macro-, microelements and amino acids; the studied agrochemicals generate a uniform film of preparation with optimal adhesion, reduce stress symptoms and protect plants from unfavorable environmental factors, ensure rapid delivery of nutrients due to low $\mathrm{pH}$.

The obtained experimental data were mathematically processed using generally accepted methods of descriptive statistics, Statistica 6.0 and Ms Excel software. The confidence level of statistical analysis amounted to 0.95 (95\%).

\section{Results and Discussion}

In the Mountain-Valley Crimea, weather conditions of the cropping season of 2019-2020 were favorable for vine growth and development. Going through all phenological phases of grape vegetation during the years of research in terms of timeline did not impact long-time average annual indicators.

The experiment was based on grape plants of similar potential productivity. Bush loading with inflorescences on average over the years of research was $15.5 \mathrm{pcs} / \mathrm{bush}$, therefore, the potential increase in yield could depend only on the average bunch weight indicator. In the course of research, the effect of micronutrient fertilizers on the number of bunches (inflorescences) was not established, while the coefficients of fruiting $\left(K_{1}\right)$ and fertility $\left(\mathrm{K}_{2}\right)$ amounted to 1.2 and 1.3 in experimental variants, respectively.

In the course of our research work, phytometric indicators of grapevine, which are an important criterion for obtaining high yield of grape plantations, were determined. It was found that using of experimental system of mineral nutrition in one plot of grapes for two years contributed to an increase in the amount of bush growth by $165.1 \mathrm{~cm}^{3}(9.1 \%)$ and average shoot length by $15 \mathrm{~cm}(9.2 \%$, Table 2$)$. In terms of values of such indicators as average shoot diameter and ripening of annual shoots of grapes, regardless the variant of experiment, no significant differences were found (Table 2). At the same time, annual grape shoots in the third decade of September were ripe by $90.1-91.7 \%$ of the total shoot length (ripening is classified as good). In terms of vigor, grape shoots were medium-grown.

Table 2. The effect of the studied nutrition system on phytometric indicators of grapes

('Italia' variety, average of 2019-2020).

\begin{tabular}{|c|c|c|c|c|c|}
\hline Variant & $\begin{array}{c}\text { Average shoot } \\
\text { length (L), cm }\end{array}$ & $\begin{array}{c}\text { Average shoot } \\
\text { diameter (D), } \\
\mathrm{cm}\end{array}$ & $\begin{array}{c}\text { Leaf surface } \\
\text { area (S), } \mathrm{m}^{2}\end{array}$ & $\begin{array}{c}\text { Amount of } \\
\text { bush growth } \\
(\mathrm{P}), \mathrm{cm}^{3}\end{array}$ & $\begin{array}{c}\text { Ripening, } \\
\%\end{array}$ \\
\hline & \multicolumn{5}{|c|}{ For the first decade of September } \\
\hline Control & 162.6 & 0.83 & 5.32 & 1814.8 & 91.7 \\
\hline Experiment & 177.6 & 0.83 & 5.68 & 1979.9 & 90.1 \\
\hline $\mathrm{HCP}_{05}$ & 8.5 & 0.03 & 0.3 & 72.7 & - \\
\hline
\end{tabular}

Verification of the yield of industrially ripe grapes showed that experimental variant exceeded the control in all parameters under study. Using of experimental system of nutrition on table grapes contributed to an increase in the average bunch weight by $42.9 \mathrm{~g}$ (7.4\%), an increase in the yield per bush indicator by $0.9 \mathrm{~kg} /$ bush $(10.2 \%)$ and cropping 
capacity by $1.8 \mathrm{t} / \mathrm{ha}(10.2 \%$, Table 3$)$. In the course of calculations provided in terms of productivity of annual shoots, it was found that the experiment exceeded the control by $51.5 \mathrm{~g}(8.1 \%)$. In terms of such quality indicators as mass concentration of sugars and titratable acids, the grape yield of the experimental plot and the control one was at the same level: $197-203 \mathrm{~g} / \mathrm{dm}^{3}$ and 6.1-6.2 $\mathrm{g} / \mathrm{dm}^{3}$, respectively (Table 3).

Table 3. The effect of the studied nutrition system on grape yield quality and productivity ('Italia' variety, average of 2019-2020).

\begin{tabular}{|c|c|c|c|c|c|c|}
\hline \multirow{2}{*}{ Variant } & \multirow{2}{*}{$\begin{array}{c}\text { Average } \\
\text { bunch } \\
\text { weight, } \mathrm{g}\end{array}$} & \multirow{2}{*}{$\begin{array}{c}\text { Number of } \\
\text { bunches, } \\
\text { pcs./bush }\end{array}$} & \multirow{2}{*}{$\begin{array}{c}\text { Yield, } \\
\mathrm{kg} / \mathrm{bush}\end{array}$} & $\begin{array}{c}\text { Cropping } \\
\text { capacity, } \\
\mathrm{t} / \mathrm{ha}\end{array}$ & \multicolumn{2}{|c|}{$\begin{array}{c}\text { In grape berry juice mass } \\
\text { concentration of }\end{array}$} \\
\cline { 6 - 8 } & & & & $\begin{array}{c}\text { sugars, } \\
\mathrm{g} / \mathrm{dm}^{3}\end{array}$ & $\begin{array}{c}\text { titratable } \\
\text { acids, } \mathrm{g} / \mathrm{dm}^{3}\end{array}$ \\
\hline Control & 578.9 & 15.2 & 8.8 & 17.6 & 197 & 6.1 \\
\hline Experiment & 621.8 & 15.6 & 9.7 & 19.4 & 203 & 6.2 \\
\hline $\mathrm{HCP}_{05}$ & 18.9 & 0.6 & 0.4 & 0.9 & 6.7 & 0.3 \\
\hline
\end{tabular}

At the next stage of the work, the analysis of mechanical composition of table grape bunches was carried out. The registered statistically significant increase in the average bunch weight in experimental variants was due to an increase in the weight of 100 berries by $65.8 \mathrm{~g}(10.5 \%)$ in comparison with the control, at the same time there was an increase in the index of bunch structure by $4.7 \%$ (Table 4 ).

Table 4. The effect of the studied nutrition system on mechanical composition of grape bunch ('Italia' variety, average of 2019-2020).

\begin{tabular}{|c|c|c|c|c|c|c|c|c|}
\hline \multirow{3}{*}{ Variant } & \multicolumn{8}{|c|}{ Bunch structure } \\
\hline & \multirow{2}{*}{$\begin{array}{c}\text { Bunch } \\
\text { weight, g }\end{array}$} & \multirow{2}{*}{$\begin{array}{l}\text { Number of } \\
\text { berries per } \\
\text { bunch, pcs. }\end{array}$} & \multirow{2}{*}{$\begin{array}{c}\text { Weight } \\
\text { of } 100 \\
\text { berries, } g\end{array}$} & \multirow{2}{*}{$\begin{array}{c}\text { Stem } \\
\text { weight, } \\
\mathrm{g}\end{array}$} & \multirow{2}{*}{$\begin{array}{c}\% \\
\text { of berries }\end{array}$} & \multirow{2}{*}{$\begin{array}{c}\% \\
\text { of } \\
\text { stem }\end{array}$} & \multicolumn{2}{|c|}{ Index of } \\
\hline & & & & & & & structure & berry \\
\hline Control & 578.9 & 84.6 & 628.3 & 8.5 & 98.5 & 1.5 & 65.7 & 14.6 \\
\hline Experiment & 621.8 & 83.9 & 694.1 & 8.5 & 98.6 & 1.4 & 70.4 & 13.5 \\
\hline $\mathrm{HCP}_{05}$ & 18.9 & 2.5 & 32.6 & 0.3 & - & - & - & - \\
\hline
\end{tabular}

At the final stage of the work, a tasting assessment of 'Italia' table grapes was carried out using 10-point scale (according to the scheme): 1) external appearance (elegance); 2) flavor and aroma of berries; 3 ) skin and pulp characteristics. The obtained information is presented in Table 5.

It should be noted that using of experimental system of nutrition on the first year of research did not have a significant effect on grape organoleptic indicators, the assessment of the control and experimental variants was at the same level of 8.1-8.2 points (Table 5).

Grape tasting assessment carried out in 2020 showed that using of experimental nutrition system in one plot of table grapes for the second year contributed to an increase in all organoleptic indicators. As the final result, the experimental sample received a very high assessment -9.5 points (Table 5).

Table 5. Organoleptic assessment of table grape variety 'Italia' when using the studied systems of grape nutrition.

\begin{tabular}{|c|l|c|}
\hline Variant & \multicolumn{1}{|c|}{ Organoleptic assessment } & $\begin{array}{c}\text { Average } \\
\text { Score }\end{array}$ \\
\hline \multicolumn{1}{|c|}{2019} & $\mathbf{1}$ \\
\hline Control & $\begin{array}{l}\text { Bunch is typical for this variety, but berries are not uniform. } \\
\text { Balanced Muscat flavor. Pulp is juicy, fleshy. Skin breaks when } \\
\text { eaten, almost not felt. }\end{array}$ & $\begin{array}{l}\mathbf{8 . 1} \\
\text { Bunch is more elegant and aligned in comparison with the control. } \\
\text { Experimes are larger. Amber color. Flavor is Muscat, but less }\end{array}$ \\
\hline
\end{tabular}




\begin{tabular}{|c|l|c|}
\hline \multicolumn{2}{|c|}{ pronounced. Acidity is higher. Pulp is juicy. Skin is difficult to eat. } \\
\hline Control & $\begin{array}{l}\text { Bunches are smaller and not typical. Balanced Muscat flavor. Pulp } \\
\text { is crispy, firm. Skin is eatable. }\end{array}$ & $\mathbf{8 . 6}$ \\
\hline Experiment & $\begin{array}{l}\text { Bunch is elegant, typical for this variety. Large berries. } \\
\text { Outstanding balanced, Muscat flavor. Pulp is juicy, flashy. Skin is } \\
\text { firm, but eatable. }\end{array}$ & $\mathbf{9 . 5}$ \\
\hline
\end{tabular}

\section{Conclusion}

Thus, the studies on biological regulation of using mineral gel fertilizers of new generation manufactured by Agrinos and Lima-Europe companies in the conditions of the MountainValley Crimea on table variety 'Italia' proved their positive effect on productivity of grape plants. A significant increase in phytometric, quantitative and qualitative indicators of the yield was established:

- the obtained data analysis by phytometric indicators showed that experimental variant exceeded the control by an average of $15 \mathrm{~cm}(9.2 \%)$ and $165.1 \mathrm{~cm}^{3}(9.1 \%)$ in terms of average length of annual shoots and bush growth, respectively;

- a significant increase in yield of 'Italia' variety amounted to $1.8 \mathrm{t} / \mathrm{ha}(10.2 \%)$, and was obtained due to statistically reliable increase in the average bunch weight by $42.9 \mathrm{~g}$ in comparison with the control;

- the analysis of mechanical composition of grape bunch in experimental system of foliar treatments showed an increase in the bunch structure indicator by $4.7 \%$ to $70.4 \%$;

- in terms of such quality indicators of grape yield as concentration of sugars in berry juice, titratable acids and glucoacidometric indicator, the experimental variant was conditional and at the level of the farming system of nutrition;

- according to the results of tasting assessment, when using experimental system of nutrition with mineral gel fertilizers of new generation during two years in one plot of 'Italia' table grapes, a significant increase in all organoleptic indicators was observed: appearance, flavor, aroma of berries. The grapes of experimental plot were especially distinguished by balance and uniformity against the background of control (the farming system of nutrition) and gained the best assessment, receiving a very high score -9.5 .

\section{References}

1. E.A. Yegorov, G.A. Shadrina, G.A. Kochian, Fruit growing and viticulture of South Russia, 61 (1), 1-15 (2020)

2. D.E. Russo, A.A. Krasilnikov, O.N. Sheludko, Fruit growing and viticulture of South Russia, 67, 261-282 (2021)

3. N.V. Aleinikova, I.V. Peskova, E.V. Ostroukhova, Y.S. Galkina, P.A. Didenko, P.A. Probeigolova, N.Y. Lutkova, Foods and Raw Materials, 9, 224-233 (2021)

4. I. Grechi, Ph. Vivin, G. Hibert, S. Milin, T. Robert, J.-P. Gaudillere, Environmental and Experimental Botany, 59, 139-149 (2007)

5. M. Beibulatov, R. Buival, N. Urdenko, N. Tikhomirova, Fruit growing and viticulture of South Russia, 59, 78-91 (2019)

6. S.V. Levchenko, A.A. Batukaev, I.A. Vasylyk et el., Advances in Engineering Research, 151, 900-904 (2018)

7. S. Frost, L. Lerno, J. Zweigenbaum, H. Heymann, S. Ebeler, Molecules, 23 (10), 2687 (2018) 
8. V.G. Sychev, O.A. Shapoval, I.P. Mozharova et al. Guidelines for the registration tests of agrochemicals in agriculture: production and practical edition (Moscow), LLC «Plodorodie» (2018) 